\title{
An Intact Intermediate Filament Network Is Required for Collateral Sprouting of Small Diameter Nerve Fibers
}

\author{
Teri Belecky-Adams, ${ }^{1}$ Michael Holmes, ${ }^{5}$ Yuqing Shan, ${ }^{1}$ C. Susan Tedesco,${ }^{2}$ Carla Mascari, ${ }^{2}$ Ajay Kaul, ${ }^{3}$ David C. Wight, ${ }^{4}$ \\ Randal E. Morris, ${ }^{1}$ Mark Sussman, ${ }^{3}$ Jack Diamond, ${ }^{5}$ and Linda M. Parysek ${ }^{1}$ \\ Departments of ${ }^{1}$ Cell Biology, Neurobiology, and Anatomy, ${ }^{2}$ Anesthesia, and ${ }^{3}$ Pediatrics, University of Cincinnati College of Medicine, Cincinnati, Ohio \\ 45267-0521, ${ }^{4}$ Edison Center for Biotechnology, Ohio University, Athens, Ohio 45701-2979, and ${ }^{5}$ Department of Psychiatry and Behavioural Neurosciences, \\ McMaster University, Hamilton, Ontario, Canada L8N 3Z5
}

\begin{abstract}
Expression of the intermediate filament (IF) protein peripherin is initiated during development at the time of axonal extension and increases during regeneration of nerve fibers. To test whether the IF network is essential for neuron process outgrowth in the mature organism in vivo, we disrupted endogenous peripherin IF in small-sized dorsal root ganglion (DRG) neurons in transgenic mice via expression of a mutant peripherin transgene under control of peripherin gene regulatory sequences. Anatomical and functional analyses showed that these neurons send peripheral and central axonal projections to correct targets, express correct neuropeptides, and mediate acute pain responses normally. However, disruption of IF significantly impaired the ability of uninjured small-sized DRG neurons to sprout collateral axons into adjacent denervated skin, indicating a critical role for intact IF in plasticity, specifically in compensatory nociceptive nerve sprouting.
\end{abstract}

Key words: peripherin; intermediate filament; neurofilament; unmyelinated; collateral sprouting; dorsal root ganglion; primary sensory neuron; pain; nerve growth factor

\section{Introduction}

Intermediate filaments (IFs), particularly the neurofilament triplet proteins, are believed to be important in the maintenance of axonal caliber (Julien, 1999). This is of consequence because achievement of sufficient axonal diameter encourages axonal myelination (Voyvodic, 1989), thereby promoting rapid impulse conduction. However, $\sim 65 \%$ of primary sensory neurons and most autonomic and enteric neurons possess small caliber axons that are unmyelinated. Nothing is known about the role of IFs in these fibers, although a majority express a distinct neuronal IF protein, peripherin (Leonard et al., 1988; Parysek and Goldman, 1988).

Clues to the function of peripherin IFs may lie in observations that peripherin expression correlates with nerve growth. In the developing mouse and rat embryo, peripherin expression is initiated in dorsal root ganglion (DRG) neurons because neurites extend to target tissues (Escurat et al., 1990; Gorham et al., 1990; Troy et al., 1990a), and in the adult, peripherin expression is

\footnotetext{
Received June 2, 2003; revised Sept. 1, 2003; accepted Sept. 3, 2003.

This work was supported by National Institute of Neurological Disorders and Stroke Grant 35313. We thank Tom Uveges and Jeff Kaufhold for research assistance, Dr. Gerry Shaw for his generous contribution of affinity-purified $\alpha$-internexin antibody, Dr. Rakesh Shukla (University of Cincinnati Biostatistical Center) for help with statistical analyses, Dr. Lloyd Greene for his kind gift of peripherin antibody, and Dr. Robert Brackenbury for helpful comments on this manuscript.

Correspondence should be addressed to Linda Parysek, Vontz Center for Molecular Studies, Department of Cell Biology, Neurobiology, and Anatomy, 3125 Eden Avenue, P.0. Box 670521, Cincinnati, OH 45267-0521. E-mail: linda.parysek@uc.edu.

T. Belecky-Adams's present address: Indiana University Purdue University, Indianapolis, Department of Biology, 723 West Michigan Street, Indianapolis, IN 46220.

Copyright $\odot 2003$ Society for Neuroscience $\quad$ 0270-6474/03/239312-08\$15.00/0
}

enhanced during regrowth after nerve injury in large-sized neurons of the DRG and in lower motor neurons (Oblinger et al., 1989; Troy et al., 1990b).

A particularly useful paradigm for directly testing the role of peripherin in axonal growth is the skin denervation-induced growth of collateral sprouts from neighboring uninjured neurons (Diamond and Foerster, 1992). In this compensatory sprouting response, which is similar to repair after human skin and nerve damage (Inbal et al., 1987; Ahcan et al., 1998), rodent autonomic and nociceptive functions are restored to damaged skin as a result of collateral sprouting of surviving autonomic (Gloster and Diamond, 1992), small myelinated mechanonociceptive (Nixon et al., 1984), and unmyelinated heat-nociceptive (Doucette and Diamond, 1987) fibers. Both the nociceptive and autonomic sprouting are NGF-dependent processes (Diamond et al., 1987; Diamond et al., 1992b; Gloster and Diamond, 1992). Because peripherin expression is known to be NGF-inducible in vitro (Leonard et al., 1987) and is particularly prominent in unmyelinated fibers, which mediate pain and temperature sensation, and in the autonomic nervous system, the NGF-driven sprouting paradigm is particularly appropriate for testing the role of peripherin.

To examine the function of peripherin IFs in the growth and function of primary sensory neurons, a mutant peripherin transgene under regulatory control of peripherin genomic elements was introduced into the germ line of transgenic mice. Studies of the effects of IF disruption as a result of mutant IF subunit gene expression in transgenic mice have substantiated a role for keratin IFs in maintaining the integrity of epithelial tissue (Vassar et al., 1991; Fuchs et al., 1992) and of desmin IFs in maintaining the 
normal structure of muscle (Raats et al., 1996). Dominantnegative studies provide experimental advantages when IF gene knock-outs result, for example, in death of the very cells one wishes to study, as in the case of the peripherin knock-out (Lariviere et al., 2002). Additionally, they provided a model for autosomal dominant human diseases caused by mutations in IF genes (Fuchs and Cleveland, 1998; Goudeau et al., 2001). Expression of mutant peripherin devastated the endogenous peripherin network in small-sized DRG neurons. We tested the effects of IF network disruption on functions of these sensory neurons in vivo and found that peripherin IFs are required for collateral sprouting.

\section{Materials and Methods}

Generation of transgenic mice. All procedures involving mice were approved by the University of Cincinnati Animal Care and Use Committee before the initiation of these studies.

To prepare the Periph/Disrupter (see Fig. 1) transgene, $5.8 \mathrm{~Kb}$ of rat peripherin gene $5^{\prime}$ flanking sequence was fused to a mutant peripherin gene at the PstI site at the cap site of the gene (Thompson and Ziff, 1989). The 255 bp deletion in Disrupter removed intron 4 and parts of exons 4 and 5 , sequences encoding a portion of the rod domain known to be critical for IF assembly. Fifty-five amino acids, starting at ALRDIRA at the beginning of Coil 2 in the rod domain and ending QEMNESR, were deleted. Construction of Periph/Periph-myc (see Fig. 1) mice was described by Belecky-Adams et al. (1993). Each transgene contained sequences encoding a human c-myc peptide in exon 9 of the peripherin gene to aid in immunohistochemical localization of the transgene product.

Transgenic mice were generated according to standard protocols (Chen et al., 1991). Linearized transgene DNA, devoid of plasmid sequences, was injected into the male pronucleus of mouse oocytes obtained from F1 hybrid animals of SJLxC57BL6 matings. Mice bearing the transgenes were identified by Southern analyses (Sambrook et al., 1989) of DNA isolated from tails. Founder animals and their offspring were mated to F1 SJLx57BL6 hybrid mice from Jackson Laboratories (Bar Harbor, ME) to maintain a hemizygous line.

Tissue preparation, immunohistochemistry, and antibodies. Tissues used for localization of neuropeptides were derived from mice anesthetized with Avertin $(0.125 \mathrm{gm} / \mathrm{Kg})$, perfusion fixed through the left ventricle of the heart with $4.0 \%$ paraformaldehyde in $0.05 \mathrm{M}$ phosphate buffer, $\mathrm{pH} 7.2$, postfixed with the same solution for $4 \mathrm{hr}$, and cryoprotected with $30 \%$ sucrose in $0.1 \mathrm{~m}$ phosphate buffer for $24-48 \mathrm{hr}$. Fixed tissues were embedded, frozen in a dry ice-ethanol bath, and stored at $-80^{\circ} \mathrm{C}$ until they were sectioned on a cryostat. Neuropeptide immunoreactivity [Substance $\mathrm{P}$ and calcitonin gene-related peptide (CGRP)] was assayed on sections $(10 \mu \mathrm{m})$ of perfusion-fixed tissue that were incubated in $10 \%$ normal goat serum for $20 \mathrm{~min}$ and then primary antibody diluted in Tris saline with $0.4 \%$ Triton X-100 (TSTX) overnight at $4^{\circ} \mathrm{C}$. After washing, tissue was treated with biotinylated IgG (Kirkegaard \& Perry, Gaithersburg, MD) at 1:500 in TSTX for $2 \mathrm{hr}$ and Texas Red Avidin at 1:800 in TS for $1 \mathrm{hr}$. DRG tissue used for all other indirect immunofluorescence was frozen as unfixed material, sectioned by cryostat $(6-10$ $\mu \mathrm{m})$, and then fixed in dry $-20^{\circ} \mathrm{C}$ methanol.

DRGs for whole-cell analyses were dissected and dissociated as described by Delree et al. (1989). After trypsin inactivation, DRGs were mechanically dissociated and cytocentrifuged onto glass slides for $6 \mathrm{~min}$ at $500 \mathrm{rpm}$ using a Cytospin 2 cytocentrifuge (Shandon-Lipshaw, Pittsburgh, PA). Immediately after cytocentrifugation, cells were fixed in $-20^{\circ} \mathrm{C}$ methanol and then immunolabeled as described by Foley et al. (1991). Whole-gut wall preparations (Bjorklund et al., 1984) were derived from the distal ileum $\sim 10 \mathrm{~mm}$ proximal to the ileocecal junction and were immunolabeled as described above after fixation in $4.0 \%$ paraformaldehyde for $30 \mathrm{~min}$.

Transgene fusion protein was detected using undiluted culture supernatant from a hybridoma secreting a monoclonal antibody to a human c-myc peptide (American Type Culture Collection, Manassas, VA) (Evan et al., 1985). An affinity-purified rat peripherin fusion protein antibody made in rabbit was used at a dilution of 1:50 (for sections) or 1:100 (for cytocentrifuged cells) to detect endogenous and transgene peripherin protein. Culture supernatant containing a monoclonal antibody directed against the 150 and $68 \mathrm{kDa}$ neurofilament proteins (Parysek and Goldman, 1987) was used at a concentration of 3:4 (sections) or 1:2 (cytocentrifuged cells) in TSTX. An antibody raised against a peptide representing the last 19 amino acids of the peripherin protein, which only recognized endogenous peripherin and not transgene protein, was a kind gift from Dr. Lloyd Greene (Columbia University, New York, NY) and was used at a concentration of 1:100. Other antibodies used in this study include: a polyclonal antibody to PGP9.5 (Accurate Chemicals, Westbury, NY), a polyclonal antibody to Substance $\mathrm{P}$ (Incstar, Stillwater, MN), and a polyclonal antibody to CGRP (Zeneca, Macclesfield, UK). Some sections were counterstained with Hoechst dye $(0.25 \mu \mathrm{g} / \mathrm{ml}$ of stock; Sigma, St. Louis, MO) at 1:5000 in TS. Photomicrographs of labeled tissue and cells were taken on a Zeiss (Thornwood, NY) Axiophot and recorded on film, and the whole-gut wall preparations were examined in a Molecular Dynamics (Sunnyvale, CA) confocal microscope and recorded digitally.

For data reported in Table 1, IF expression patterns of DRG neurons were assessed by immunofluorescence on cytocentrifuged DRG preparations from three mice of each genotype. For data reported in Table 2, sizes of cells displaying specific IF expression patterns were measured in semithin sections of three mice of each genotype by use of an eyepiece reticle. Neurons were size-classed according to Tennyson and Gershon (1984); small neurons were between $25-400 \mu \mathrm{m}^{2}$, medium neurons were between $401-900 \mu \mathrm{m}^{2}$, and large neurons were $>900 \mu \mathrm{m}^{2}$. The percentage of cells displaying each phenotype was calculated on the basis of the total number of cells counted from all three mice.

Hotplate test. Fifteen disrupter and fifteen wild-type littermate males were selected randomly at $9-11$ weeks of age and then individually housed in the testing room at $21^{\circ} \mathrm{C}$ on a $12 \mathrm{hr}$ light/dark cycle with food and water provided ad libitum. All mice were thoroughly conditioned to handling and the hotplate apparatus (Model 39D; Life Sciences, Hialeah, $\mathrm{FL})$ over a 3 week period. The hotplate surface $(10.5 \times 11.5$ inches $)$ was surrounded by 11 inches high Plexiglas walls to form a chamber. Six days each week, each mouse was held by the same investigator throughout the study for a minimum of $5 \mathrm{~min}$. During the third week, the mice were placed on the hotplate, which had been warmed to $40^{\circ} \mathrm{C}$, for 5 min each day. For the fourth and fifth weeks, hotplate data were collected on Monday, Wednesday, and Friday between 4:00 and 10:00 P.M., whereas the standard conditioning continued on remaining days. The surface was maintained at $50 \pm 0.5^{\circ} \mathrm{C}$ (Tjolsen et al., 1991) during testing, which was conducted simultaneously by two investigators (to maximize behavioral observations) who were blind to the genotype of the animals. For the test, each mouse was removed from its home cage, held for 1-2 min until still, and placed on the middle of the hotplate. The mouse was removed from the chamber as soon as the behavioral endpoint of hindpaw lick was seen, or the maximum exposure period of $30 \mathrm{sec}$ had elapsed.

Each mouse underwent four trials per testing day with a 15 min delay between trials. Mice were tested in small groups (of six) so that all data were collected on each animal at the same time each day. To assess the overall performance of each group, the average of each mouse on each day was then averaged with all mice of the same genotype each day. Finally, all $6 \mathrm{~d}$ were averaged, and SEM was calculated.

Carmine dye method for measurement of whole-gut transit time. After an overnight fast, allowing only water, and brief anesthesia with methoxyfluorane, $0.3 \mathrm{ml}$ of a $0.5 \%$ solution of carmine red dye was gavaged into the stomach using a 7 French diameter polyvinyl-feeding catheter. The mice continued to fast after introduction of the dye. The whole-gut transit of the dye was measured as the time taken after administration for the colored dye to appear in the fecal pellet. The mice were killed at the end of the study, and the total length of the small intestine and colon were measured on a vertical scale by attaching a known weight to the bottom end and allowing it to hang freely (Helmrath et al., 1996). Transit time was expressed as a function of the total length of intestine traveled (Baldrick et al., 1998).

Collateral sprouting assay. The sprouting assays were performed on age-matched "disrupter mice" and control littermates as described previously (Lourenssen et al., 2000), except that Avertin was used as the surgical anesthesia. Similar numbers of female and male mice were tested 


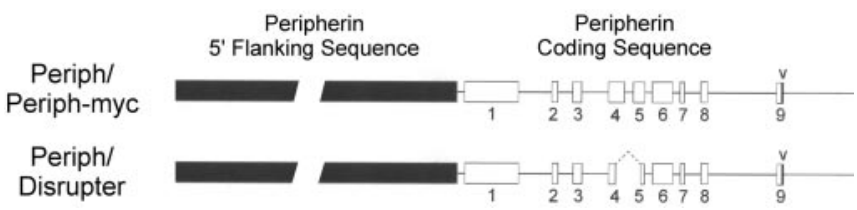

Figure 1. Graphic representation of the transgenes. A dominant-negative mutant peripherin/transgene, Periph/Disrupter, was constructed by removing intron 4 and parts of exons 4 and 5 (stippled box) from a full-length myc-tagged peripherin transgene (Periph/Periph-myc). To facilitate immunolocalization of transgene protein products, both transgenes contained sequence encoding a human c-myc peptide inserted into the $3{ }^{\prime}$ end of the coding portion of exon $9(v)$.

in each group. The field of innervation of the dorsal cutaneous nerve (DCN)-T13 on the mouse back was "isolated" by surgically cutting the DCNs three to four segments above and below T13, effectively denervating the skin surrounding the DCN-T13 nerve field. In this condition, the levels of NGF in the denervated skin rise (Mearow et al., 1993), evoking sprouting of the neighboring nociceptive fibers in the isolated innervation area and causing a progressive expansion of the mechanonociceptive ("pinch") and heat-nociceptive (heat) fields subserved by Adelta and C fibers, respectively (Diamond et al., 1987). The two sensitive areas were mapped separately using the cutaneous truncus muscle reflex, a skin twitch of the underlying cutaneous truncus muscle, evoked by forceps pinch or $60^{\circ} \mathrm{C}$ probe stimulus (Diamond et al., 1992a). The mapping was performed on days 0 and 21 , the field borders were traced and transferred to transparent plastic sheets, and the areas were measured using NIH Image. We evaluated the statistical significance of increases in field sizes at day 21 relative to day 0 in three ways. We analyzed the ratio of expansion by the nonparametric Wilcoxon test and, because the ratios were normally distributed and the groups had equal variances, we also used parametric $t$ tests. Additionally, we used ANCOVA analysis of the day 21 area values, with day 0 treated as the covariate to analyze the significance of the raw area data. A sprouting deficit detected in the initial test was confirmed on a second set of mice tested later. Results from both sets of mice were similar and were combined in the final presentation of the sprouting figure.

\section{Results}

Generation and initial characterization of mice carrying a mutant peripherin transgene

To study the role of the cytoplasmic IF network in the morphology and function of small-diameter primary sensory neurons, a mutant peripherin transgene previously shown to disrupt the IF network in PC12 cells (Parysek et al., 1991) was expressed under control of sequences required for cell type-specific expression of the peripherin gene (Belecky-Adams et al., 1993) in transgenic mice (Fig. 1). Injection of the transgene into fertilized mouse oocytes resulted in five founder mice, four of which were fertile. Progeny from these four founders expressed the transgene, indicated by c-myc epitope expression in nervous tissue as assessed by immunofluorescence.

To assess whether the mutant peripherin protein expressed in these mice disrupted the endogenous cytoplasmic filament network, antibodies to peripherin and the c-myc epitope were used to examine the cytoskeleton in the major peripherin-expressing cell type in the adult, the small-sized DRG neuron. In two lines, filamentous labeling in the small-sized DRG neurons was completely absent. Cells from the two fully disrupted lines (disrupter mice) contained globules of $m y c$-labeled transgene protein surrounding the nucleus and scattered in the cytoplasm (Fig. 2A, arrows). A similar labeling pattern was obtained with a peripherin antibody (Fig. $2 \mathrm{~B}$ ), indicating endogenous peripherin filaments were also fully disrupted. This pattern was in striking contrast to the filamentous labeling pattern seen with either myc or

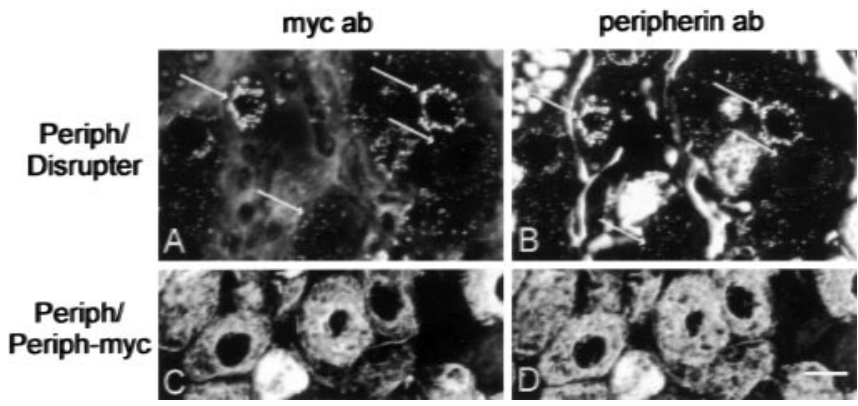

Figure 2. The peripherin network is collapsed in the small-sized DRG neurons that express the disrupter transgene. $A-D$, Sections of $D R G$ s derived from adult disrupter mice $(A, B)$ and periph-myc control mice $(C, D)$ double labeled with antiserum to peripherin $(B, D)$ and antibody to the human c-myctag $(A, C)$ showed that small-sized neurons $(A, B$, arrows) contain globules labeled with peripherin and myc antibodies but no filamentous network. In control DRG $(C, D)$, filamentous arrays in small-sized cell bodies are colabeled with both myc antibody and peripherin antiserum $(C, D)$. Scale bar, $10 \mu \mathrm{m}$.

peripherin antibodies in control mice expressing a full-length, nondisrupting, $m y c$-tagged rat peripherin transgene (Fig. $2 C, D$ ) (Belecky-Adams et al., 1993). It is likely that all IFs in the smallsized DRG cells were disrupted, because antibody to $\alpha$-internexin, the only other IF protein known to be expressed in these small-sized cells, also labeled only a globular pattern (data not shown).

Additional analysis of peripherin antibody-labeled disrupter mouse DRG sections indicated that, in addition to small-sized DRG neurons (Fig. 3A, arrows), globules of peripherin were also present in large-sized DRG neurons (Fig. 3A, arrowheads). In adult mice, the large-sized cells normally express only the neurofilament triplet proteins [neurofilament (NE)-L, $-\mathrm{M}$, and $-\mathrm{H}$ ], and this pattern of IF expression was seen in nontransgenic littermate controls (Fig. $3 C, D$ ) and nondisrupting peripherin-myc transgenic controls (Fig. 3E,F). Colabeling sections with NF-M and NF-H antibody showed that this ectopic expression of mutant peripherin did not disrupt the NF filaments in large-sized DRG neurons of disrupter mice. These experiments showed that, in disrupter mice, filamentous networks were preserved only in DRG neurons that expressed NF-M and - $\mathrm{H}$.

To examine the filament network of disrupter DRG cells with greater resolution, DRGs from adult disrupter mice, nontransgenic littermates, and peripherin-myc controls were dissociated, cytocentrifuged onto slides, double-labeled with peripherin antiserum and NF-M and - $\mathrm{H}$ antibody, and examined by fluorescence and confocal microscopy. These analyses confirmed that the IF network was disrupted in small neurons that expressed only peripherin and not NF-M and -H (Fig. 4, top), but was retained in large neurons that coexpressed peripherin and NF-M and -H (Fig. 4, bottom).

\section{Neurons with a disrupted IF network innervate target tissues} in a manner similar to controls

To determine whether disruption of the IF network altered the differentiation of the small-sized neurons, we assessed the expression of differentiation-specific markers that were important for the function of these neurons. Serial sections derived from disrupter and control L4 and L5 DRGs were analyzed with antisera to substance P or CGRP, and the percentage of neurons that expressed substance P or CGRP was computed by comparison to the total number of neurons determined by staining with Hoechst dye, which stains nuclei. Both control and disrupter DRGs contained substance P in $14 \%$ of DRG neurons. CGRP 
$a b$ to peripherin
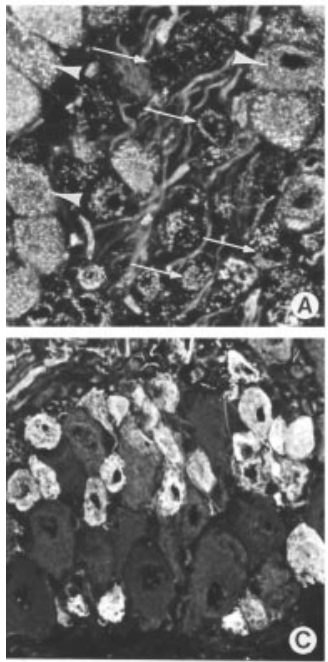

ab to NF-M + NF-H
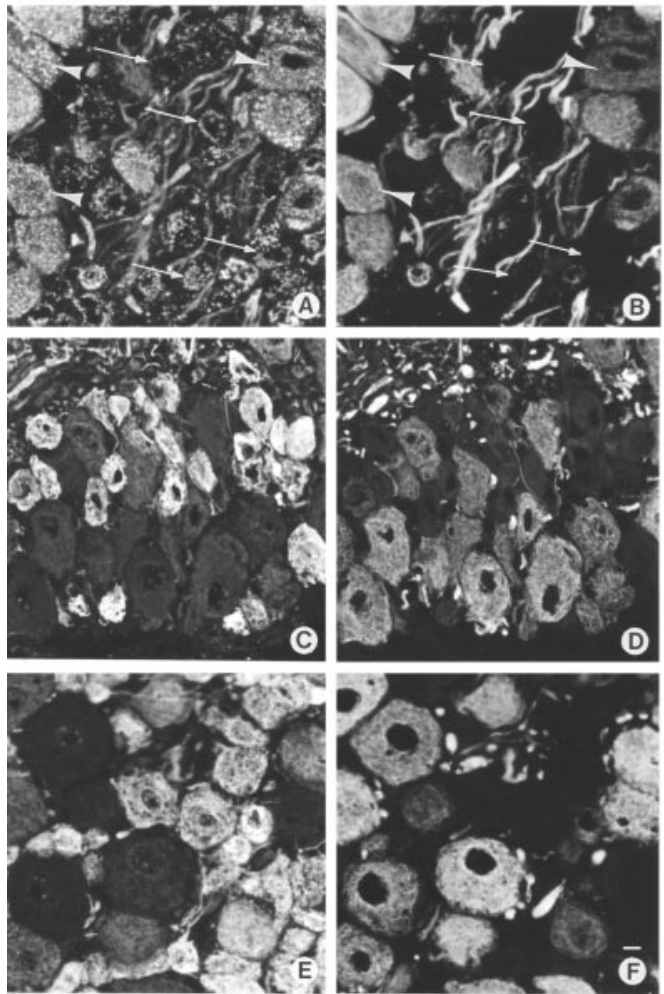

Periph/

Disrupter

non

transgenic

Periph/

Periph-myc
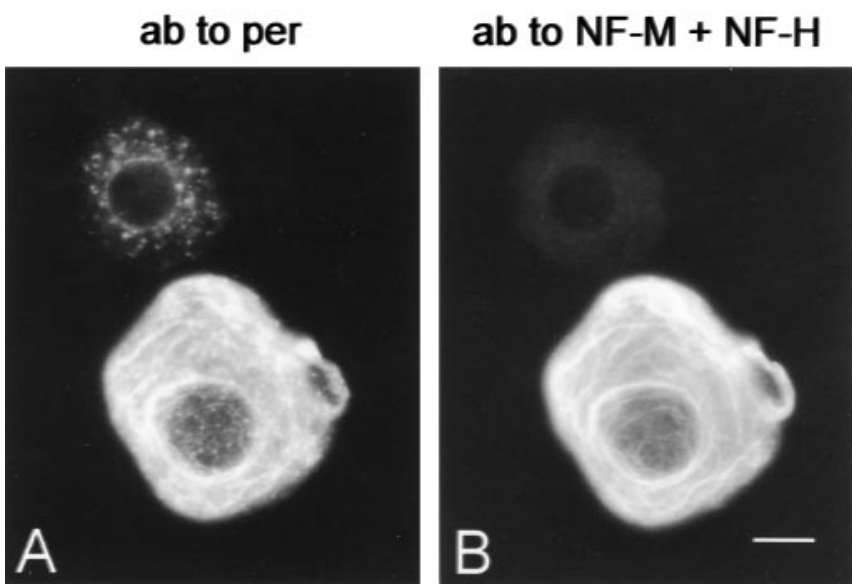

Figure 4. The increased resolution afforded by examining dissociated DRG cells confirms that there is no IF network in small-sized neurons and a peripherin-NF-M-containing network in large-sized neurons. To increase the resolution of the filament network in disrupter DRG neurons, DRGs from disrupter mice were dissociated, cytocentrifuged onto glass slides, and double labeled with antibodies to peripherin $(A)$ and NF-M/-H ( $B)$. As observed in sections, no intact peripherin network is seen in small-sized neurons $(A)$, and these neurons are not immunopositive for NF-M or NF-H ( $B)$. However, large-sized neurons still have a filamentous labeling pattern, and this network is colabeled with antibodies recognizing both peripherin $(A)$ and NF-M and NF-H (B). Scale bar, $10 \mu \mathrm{m}$.
Periph/Disrupter
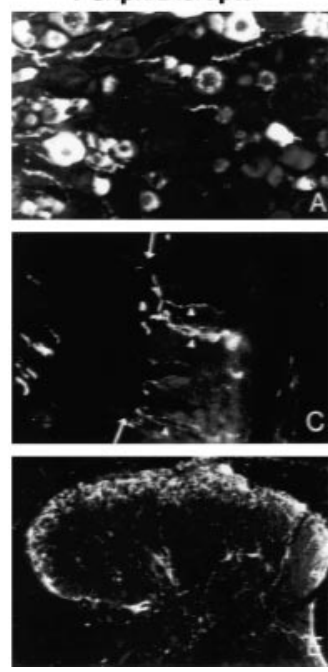

Periph/Periph-myc
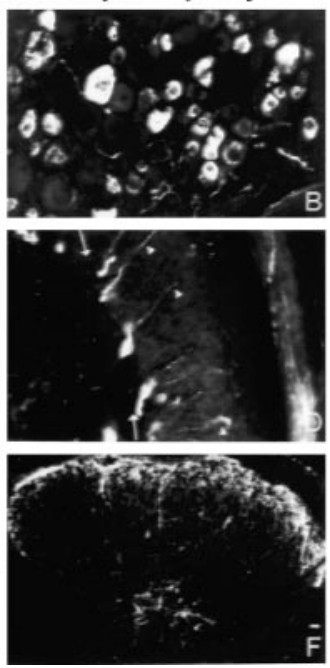

CGRP ab DRG

CGRP ab glabrous skin

CGRP ab spinal cord
Figure 5. DRG neurons without an intact IF network express correct neuropeptides and show peripheral and central innervation patterns similar to control DRG neurons. $A-F$, Sections of DRG $(A, B)$, footpad $(C, D)$, and spinal cord $(E, F)$ derived from disrupter mice $(A, C, E)$ and control littermates $(B, D, F)$ were immunolabeled with an antibody that recognizes CGRP. This neuropeptide, normally found in the small-sized neurons of the DRG, shows a similar distribution in disrupter and control DRGS $(A, B)$. Qualitatively, similar numbers of peripheral fibers from (GRPpositive DRG cells innervate the dermis of the footpad ( $C, D$, arrowheads) (arrows show boundary between epidermis and dermis). Similarly, the central fibers of (GRP-immunopositive cells give rise to an innervation pattern in laminas I and II of the lumbar spinal cord that is similar in both disrupter $(E)$ and control $(F)$ mice. Scale bar, $10 \mu \mathrm{m}$.

age and size class of neurons expressing the neuropeptides substance P and CGRP were similar in disrupter and control mouse DRG, and that the pattern of innervation of these small-sized neurons appeared to be similar in disrupter and control tissue.

that innervate the spinal cord. In control spinal cord, CGRPimmunopositive fibers were found to innervate Rexed's lamina 1 and 2 profusely, with occasional groups of fibers in laminas 3-5 (Fig. $5 F$ ). In spinal cords of disrupter mice, the spatial distribution and number of CGRP-positive fibers appeared to be similar to control mice (Fig. 5E). These results indicate that the percent-
Intact IFs are required for collateral sprouting but not regeneration of small-sized DRG neurons

Although the small-sized sensory neurons appeared to have appropriate anatomical connections in the disrupter mice, 
dominant-negative disruption of the IF cytoskeleton requires a high ratio of mutant to wild-type IF protein (Gill et al., 1990), and IF expression in embryonic DRG neurons differs from that in the adult (Goldstein et al., 1996). For these reasons, it is possible that the ratio of mutant peripherin/wild-type IF protein was insufficient to allow for complete disruption of the IF network during the period when neuronal connections were forming. Therefore, it was important to test the role of the IF network in the achievement of neuronal form in adult disrupter mice when the IF network clearly was completely disrupted.

Our initial analysis of neuronal growth focused on a simple regeneration assay. However, preliminary comparison of the number of disrupter and control littermate mice nerve fibers that regenerated $4 \mathrm{~mm}$ past a tibial nerve crush site after $56 \mathrm{~d}$ (data not shown) indicated no hint of impairment of longitudinal axonal regeneration in disrupter mice. Similarly, there was no gross impairment of the return of skin sensitivity in disrupter mice after nerve crush, although the possibility of some reduction in arborization of regenerated fibers in the skin could not be excluded completely (data not shown). The lack of a significant deficit in regeneration in vivo, but robust defect in full neurite tree development in vitro (C. A. Ebert, T. L. Belecky-Adams, T. E. Uveges, and C. M. Parysek, unpublished observations), led us to also study neurite growth in a collateral sprouting assay in vivo. This assay focuses more precisely than the regeneration assays on unmyelinated $\mathrm{C}$ and thinly myelinated Adelta sensory fibers (Nixon et al., 1984; Doucette and Diamond, 1987), the major fiber types associated with the sizes of peripherin-expressing neurons (Ferri et al., 1990) that had disrupted IFs. [The large myelinated mechanosensory touch fibers do not undergo spontaneous sprouting in adult rats (Jackson and Diamond, 1984)]. It was plausible that peripherin had a role in sprouting because collateral sprouting is an NGF-dependent process (Diamond et al., 1987), and the peripherin gene has been shown to be regulated by NGF in vitro (Thompson et al., 1992). Therefore, the capacity of the unmyelinated heat-nociceptive fibers and thinly myelinated pinchsensitive fibers to sprout into denervated skin was tested and compared in disrupter and control mice.

The field of skin on the back of the mouse that was responsive to either pinch or heat stimuli and served by an intact cutaneous branch of the T13 nerve was tested on day 0, the day in which cutaneous branches immediately above and below T13 were severed, and on day 21 after surgery, and the degree of expansion of the sensitive nerve field compared between age- and sex-matched control and disrupter mice was measured. The average day 0 field sizes were slightly larger in disrupter mice (mean, $0.58 \mathrm{~cm}^{2}$ for heat, $1.095 \mathrm{~cm}^{2}$ for pinch) compared with control mice (mean $=$ $0.46 \mathrm{~cm}^{2}$ for heat, $0.943 \mathrm{~cm}^{2}$ for pinch) before sprouting. Significantly, however, the areas of the T13 heat-sensitive fields expanded by approximately twofold (average ratio of expansion for day $21 / \mathrm{d} 0,1.87)$ in control mice $(n=18)$ but only $\sim 1.34 \times$ in disrupter mice $(n=18 ; p=0.0008$; parametric $t$ test for ratio). The expansion of the pinch-sensitive fields was also impaired significantly in disrupter mice $(1.49 \times)$ compared with control mice ( $1.81 \times ; p=0.013$; parametric $t$ test for ratio) (Fig. 6$)$. The ratio data were significant by both the parametric $t$ test for ratio and the nonparametric Wilcoxon test for ratio. Additionally, analysis of the raw area data by ANCOVA, with the day 0 value treated as covariate, showed significant differences $(p=0.0013)$ in the heat but not pinch areas. These data strongly suggest that peripherin IFs are required for the sprouting of new branches from uninjured, nociceptive peripheral nerve fibers.

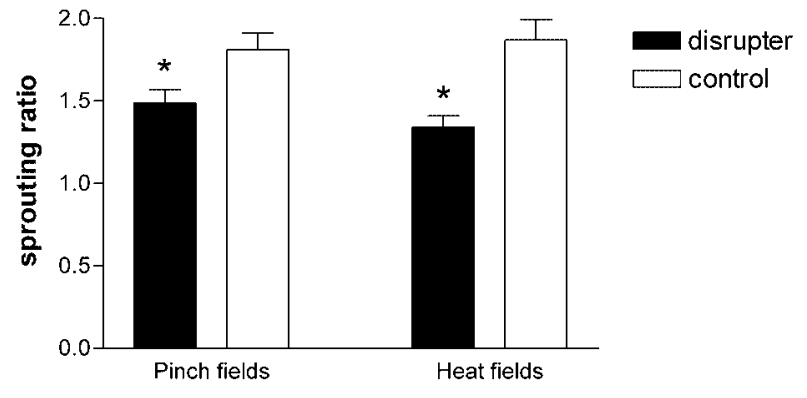

Figure 6. Collateral sprouting of heat- and pinch-sensitive, small-sized primary sensory neurons in disrupter mice is significantly reduced relative to the same population of neurons from mice with wild-type IFs. After denervation surgery that creates an "island" of normally innervated skin in a region of nonsensitive skin, sprouting of nociceptive fibers causes the expansion of initially measured (day 0 ) heat-sensitive and pinch-sensitive areas from the island. Sensitive areas were again measured at $21 \mathrm{~d}$ and compared with the size of the original areas. The average degree of expansion of heat sensitivity in control mice was $1.87 \times$ but was only $1.34 \times$ in age-matched disrupter mouse littermates $(p=0.0008)$. Expansion of the pinchsensitive fields was also reduced significantly in disrupter mice ( $p=0.017)$. The columns show mean $\pm \operatorname{SEM}(n=18)$.

\section{Intact IFs are not required for other functions of peripherin-expressing neurons}

To assess the generality of the requirement for intact IFs in neuronal function, we examined additional physiological functions of peripherin-expressing neurons. Small-sized DRG neurons are responsible for transmitting information concerning painful stimuli from the periphery to the CNS. We tested whether mice bearing the disrupter transgene were as responsive to pain stimuli as their normal littermates by comparing the latency with which disrupter and control mice respond to being placed on a $50^{\circ} \mathrm{C}$ hotplate. The mean latencies of disrupter and littermate control mice for response to the hotplate were similar $(18.3 \mathrm{sec}$; SEM, $\pm 0.56 \mathrm{sec} ; n=15)$ versus (18.7 sec; SEM, $\pm 0.5 \mathrm{sec} ; n=15$ ), indicating that IF disruption does not interfere with response to a $50^{\circ} \mathrm{C}$ heat stimulus.

We also determined whether there were abnormalities in enteric neurons, the other major neuron type that expresses peripherin as a major IF subunit. Confocal analyses of whole-gut wall preparations from disrupter mice showed that, like in sensory neurons, mutant peripherin was concentrated in neuronal cell bodies, and the IF network in peripherin-expressing gut neurons was disrupted (data not shown). Colabeling of such preparations with anti-PGP9.5, which labels all neurons (Wilkinson et al., 1989), showed that neurons expressing mutant peripherin have processes, and that the overall structure of the gut nervous system appeared indistinguishable between disrupter and control mice (data not shown). To determine whether the disrupted IF cytoskeleton in gut neurons affected their function, we compared the gut transit time relative to intestinal length of disrupter and wild-type littermate mice. The movement of carmine dye, gavaged into the stomach, was measured by determining the time at which it first appeared in fecal pellets. The gut transit rate averaged $0.73 \mathrm{~cm} / \mathrm{min}$ in disrupter mice (range, $0.33-0.97 \mathrm{~cm} / \mathrm{min}$; $n=8$ ) and $0.70 \mathrm{~cm} / \mathrm{min}$ in wild-type littermates (range, $0.42-$ $0.96 \mathrm{~cm} / \mathrm{min} ; n=9$ ), and there were no significant differences in the length of the intestinal tract (small intestine plus colon) between the two groups of mice.

\section{The alteration in large-sized neuron phenotype in disrupter mice}

Expression of peripherin in large-sized DRG neurons of disrupter mice was unexpected. We confirmed that both mutant and en- 
Table 1. Percentages of cells expressing peripherin, NF-M, or both in the total DRG neuron population from disrupter and control mice

\begin{tabular}{|c|c|c|c|c|}
\hline Mouse genotype & Peripherin + & NF-M+ & Coexpression of peripherin and NF-M & Total number of neurons counted \\
\hline Periph/disrupter transgenic & $56.6 \%$ & $4.6 \%$ & $38.9 \%$ & $n=19,727$ neurons from 3 mice \\
\hline Periph/myc transgenic & $68.9 \%$ & $24.7 \%$ & $6.4 \%$ & $n=21,400$ neurons from 3 mice \\
\hline Nontransgenic littermate & $66.5 \%$ & $21.9 \%$ & $11.6 \%$ & $n=16,969$ neurons from 3 mice \\
\hline
\end{tabular}

Table 2. Percentages of large-sized DRG neurons expressing only NF-M or both peripherin and NF-M in disrupter and control mice

\begin{tabular}{lrll}
\hline Mouse genotype & NF-M + & $\begin{array}{l}\text { Coexpression of } \\
\text { peripherin and NF-M }\end{array}$ & $\begin{array}{l}\text { Number of } \\
\text { neurons measured }\end{array}$ \\
\hline Periph/disrupter transgenic & $1.0 \%$ & $33.3 \%$ & 983 \\
Periph/myc transgenic & $16.5 \%$ & $9.0 \%$ & 1030 \\
Nontransgenic littermate & $18.3 \%$ & $5.0 \%$ & 1021 \\
\hline
\end{tabular}

dogenous peripherin were included in the peripherin antibodylabeled globules by labeling DRG sections from disrupter mice with an antibody to the carboxyl terminal 19 amino acids of peripherin, which were present only in endogenous peripherin (data not shown). Examination of DRG neuron preparations revealed that coexpression of peripherin and NF-M was increased (Table 1) in the large-sized neurons ( $900 \mu \mathrm{m}^{2}$ or greater) (Table 2) of disrupter mice as compared with wild-type littermates and peripherin-myc controls. This inappropriate expression could reflect alterations in the development of the large-sized cells or represent a normal injury response (Wong and Oblinger, 1990) to an altered environment of these cells in disrupter mice.

\section{Discussion}

To define the role of IFs in neurons with small-caliber projections, we tested the effect of disrupting these filaments through targeted expression of a mutant peripherin transgene. Expression of mutant peripherin induced no detectable morphological defect in peripherin-expressing enteric neurons or in the projections of small-sized DRG neurons to the skin or spinal cord in the adult mouse. In addition, disruption of IFs in small-sized DRG neurons did not interfere with their ability to mediate a response to a $50^{\circ} \mathrm{C}$ heat stimulus. However, analysis of IFs in cultured embryonic DRG neurons from disrupter mice suggested that IFs may not have been disrupted completely in these neurons during the period when axonal projections formed and thus did not provide an adequate test of the importance of IFs in the development of processes of these cells. Therefore, to determine the effect of IF disruption on nerve growth, we analyzed the ability of adult DRG sensory neurons in which IFs were disrupted fully to undergo either regeneration after nerve crush or peripheral collateral sprouting from noncrushed axons in response to adjacent skin denervation. Strikingly, IF disruption profoundly reduced the ability of these axons to sprout collateral branches.

Collateral sprouting from uninjured neurons is distinct from axonal regeneration, which is triggered by axonal damage, and from the type of sprouting ("regenerative sprouting") that is confined to the growing tip of a regenerating axon (Diamond et al., 1992c). The collateral sprouting assay in rodents specifically tests the capacity of undamaged myelinated and unmyelinated nociceptive nerve fibers in the skin to expand their terminal trees of free nerve endings in response to denervation of adjacent skin, a process that is absolutely dependent on NGF (Diamond et al., 1987, 1992a; Gloster and Diamond, 1992). Cutaneous NGF levels increase after denervation in part because of elimination of NGF uptake into nerves (Korsching and Thoenen, 1985), and in part because its production, largely in basal epithelial cells, increases after denervation (Mearow et al., 1993). NGF acts as a trophic agent that drives the sprouting of undamaged nociceptive neurons but not axonal regeneration triggered by nerve damage (Diamond et al., 1992a, b, c).

The collateral sprouting assay is particularly useful for testing neuronal function in disrupter mice, because mutant peripherin disrupted IFs precisely in those cells with the greatest capacity for collateral sprouting and for which the expansion of heat sensitivity is a precise measure of sprouting. In wild-type mice, the only neurons in the DRG that subserve heat nociception are the peripherin-expressing small-sized primary sensory neurons of the DRG (Ferri et al., 1990), 80\% of which are heat nociceptors (Kirschstein et al., 1999). In sectioned DRG and cytocentrifuged single-cell preparations, all peripherin in small cells appeared as dots distributed throughout the cell body (Figs. 2, 3, 4). $\alpha$-internexin, the only other IF subunit known to be expressed in some of these cells (Molliver et al., 1995), was not filamentous; it was only found colocalized in dot-like structures with peripherin (data not shown). We tested for spurious expression of other IF genes including vimentin, glial fibrillary acidic protein, and NF-L in these cells and found none (T.B.-A. and L.M.P., unpublished observations). The lack of peripherin in axons was severe because sections of the peripheral nerve of disrupter mice were devoid of peripherin (data not shown). Indeed, to visualize the projections of these neurons, it was necessary to use Substance P and CGRP as markers. Thus, in the adult mouse, IF protein was restricted to dots in the cell body of small-sized DRG neurons and was not detectable in axons or terminal projections of these neurons. Collateral sprouting of this heat-sensitive cell type in disrupter mice was severely inhibited, as indicated by every statistical method used to analyze the data, strongly implicating a role for IFs in this process.

A second type of neuron that sprouts collaterals, the intermediate-size class of DRG neurons with finely myelinated axons that primarily subserves mechanonociception, or pinch (Nixon et al., 1984), also expresses mutant peripherin in disrupter mice. Collateral sprouting of these pinch-sensitive fibers was reduced significantly in disrupter mice, but the fact that one of the statistical tests, the analysis of the original pinch-sensitive areas by ANCOVA, did not rise to the level of significance suggests that the effects of IF disruption on the pinch nociceptors was not as robust as the effects on heat nociceptors. The difference in impairment between the thermal nociceptors and the mechanonociceptors may be because intermediate-sized, but not small, DRG neurons coexpress NF-L, -M, and -H proteins (Ferri et al., 1990), which may have the ability to rescue the IF disrupting effects of mutant peripherin expression in these cells (Fig. 4). Thus, IFs may not have been disrupted in some (the larger) of the fibers tested in the pinch assay.

The relationship of IF disruption to the sprouting impairment is specific and strong. The number of small-sized neurons that furnished CGRP- and Substance P-positive free nerve endings to the skin was normal in disrupter mice. These cells supported a response to an acute heat stimulus that was in the normal range. 
In addition, whole-gut motility, controlled in part by peripherinexpressing enteric neurons, was unaffected. Therefore, all of these functions either do not depend on axonal IF or are rescued by nonfilamentous IF protein in the cell body, or perhaps more likely are significantly less-sensitive indicators of disrupted IFs than sprouting. However, the specific defect in collateral sprouting provides a specific mechanism for testing the role of peripherin IFs in cell physiology, a step forward in analysis of IF function.

IFs were required for expansion of peripheral neurite trees from uninjured small-sized DRG neurons in vivo (this study) and for full neurite tree development in vitro (Ebert et al., 2003). A previous study specifically linked the loss of NF-L, which severely limits the number of IFs in axons (Zhu et al., 1997), with diminished neurite tree development in large motor neurons in NF-L knock-out mice (Zhang et al., 2002). In vitro, IF loss was specifically linked to the reduction of axonal growth in Xenopus neurons (Walker et al., 2001) and process growth in astrocytes (Lepekhin et al., 2001). Involvement of IF proteins in the development of neurite trees is also supported by data showing that a particular phosphorylated epitope of NF-M is present only in turning or branching neurites in vitro (Landmesser and Swain, 1992). In disrupter mice, the defect in collateral sprouting of nociceptive axons suggests a specific role for IF networks in sprouting type growth of undamaged fibers that is NGF-dependent. This suggestion takes account of the finding that NGF-independent growth (Diamond et al., 1987, 1992b), as tested in the regeneration assays, was unimpaired in disrupter mice.

Peripherin could be required for transduction of the NGF signal or for the axonal responses that are triggered by NGF. The possibility that peripherin is important for some aspect of NGF signaling is supported by known physical interaction of peripherin with the intracellular domain of tyrosine receptor kinase A (trkA) (MacDonald et al., 1999). Peripherin could serve as a scaffolding protein in the receptor complex, similar to the proposed role of keratin 18 in the death receptor complex (Inada et al., 2001), or could be important for uptake or movement of trkA vesicles essential for some forms of trkA signaling (Ginty and Segal, 2002). The intracellular domain of trkA is on the outside of the vesicle and available for interaction with motor molecules such as dynein (Yano et al., 2001; Bhattacharyya et al., 2002) and molecular components that might facilitate their retrograde transport via dynein, like peripherin. A highly similar protein to peripherin, vimentin, is already suspected to interact with dynein (Helfand et al., 2002). Alternatively, the role of peripherin may be in the effecter side of the NGF-signaling pathway. Although it is less easy to visualize how cytoskeletal requirements may differ for collateral sprouting type growth versus regeneration of a main axon [however, there is evidence (Smith and Skene, 1997) for a differential expression of growth-related genes in the two growth states], it is reasonable to consider that the configuration of slender collaterals at sometimes right angles to the main axon may require IFs for flexible support struts or aid in physically directing needed materials, such as membrane components or mitochondria, into sprouts. The identification of a role for IFs in collateral sprout formation makes it possible to directly test these hypotheses for IF function in these fibers.

\section{References}

Ahcan U, Arnez ZM, Bajrovic F, Janko M (1998) Contribution of collateral sprouting to the sensory and sudomotor recovery in the human palm after peripheral nerve injury. Br J Plast Surg 51:436-443.

Baldrick P, Bamford DG, Tattersall ML (1998) An assessment of two gastric transport models currently used in safety pharmacology testing. Hum Exp Toxicol 17:1-7.

Belecky-Adams T, Wight DC, Kopchick JJ, Parysek LM (1993) Intragenic sequences are required for cell type-specific and injury-induced expression of the rat peripherin gene. J Neurosci 13:5056-5065.

Bhattacharyya A, Watson FL, Pomeroy SL, Zhang YZ, Stiles CD, Segal RA (2002) High-resolution imaging demonstrates dynein-based vesicular transport of activated Trk receptors. J Neurobiol 51:302-312.

Bjorklund H, Dahl D, Seiger A (1984) Neurofilament and glial fibrillary acid protein-related immunoreactivity in rodent enteric nervous system. Neuroscience 12:277-287.

Chen WY, Wight DC, Mehta BV, Wagner TE, Kopchick JJ (1991) Glycine 119 of bovine growth hormone is critical for growth-promoting activity. Mol Endocrinol 5:1845-1852.

Delree P, Leprince P, Schoenen J, Moonen G (1989) Purification and culture of adult rat dorsal root ganglia neurons. J Neurosci Res 23:198-206.

Diamond J, Foerster A (1992) Recovery of sensory function in skin deprived of its innervation by lesion of the peripheral nerve. Exp Neurol 115:100-103.

Diamond J, Coughlin M, Macintyre L, Holmes M, Visheau B (1987) Evidence that endogenous beta nerve growth factor is responsible for the collateral sprouting, but not the regeneration, of nociceptive axons in adult rats. Proc Natl Acad Sci USA 84:6596-6600.

Diamond J, Holmes M, Coughlin M (1992a) Endogenous NGF and nerve impulses regulate the collateral sprouting of sensory axons in the skin of the adult rat. J Neurosci 12:1454-1466.

Diamond J, Foerster A, Holmes M, Coughlin M (1992b) Sensory nerves in adult rats regenerate and restore sensory function to the skin independently of endogenous NGF. J Neurosci 12:1467-1476.

Diamond J, Gloster A, Kitchener P (1992c) Regulation of the sensory innervation of skin: trophic control of collateral sprouting. In: Sensory neurons: diversity, development, and plasticity (Scott SA, ed), pp 309-332. New York: Oxford UP.

Doucette R, Diamond J (1987) Normal and precocious sprouting of heat nociceptors in the skin of adult rats. J Comp Neurol 261:592-603.

Escurat M, Djabali K, Gumpel M, Gros F, Portier MM (1990) Differential expression of two neuronal intermediate-filament proteins, peripherin and the low-molecular-mass neurofilament protein (NF-L), during the development of the rat. J Neurosci 10:764-784.

Evan GI, Lewis GK, Ramsay G, Bishop JM (1985) Isolation of monoclonal antibodies specific for human c-myc proto-oncogene product. Mol Cell Biol 5:3610-3616.

Ferri GL, Sabani A, Abelli L, Polak JM, Dahl D, Portier MM (1990) Neuronal intermediate filaments in rat dorsal root ganglia: differential distribution of peripherin and neurofilament protein immunoreactivity and effect of capsaicin. Brain Res 515:331-335.

Foley J, Cohn SL, Salwen HR, Chagnovich D, Cowan J, Mason KL, Parysek LM (1991) Differential expression of N-myc in phenotypically distinct subclones of a human neuroblastoma cell line. Cancer Res 51:6338-6345.

Fuchs E, Cleveland DW (1998) A structural scaffolding of intermediate filaments in health and disease. Science 279:514-519.

Fuchs E, Esteves RA, Coulombe PA (1992) Transgenic mice expressing a mutant keratin 10 gene reveal the likely genetic basis for epidermolytic hyperkeratosis. Proc Natl Acad Sci USA 89:6906-6910.

Gill SR, Wong PC, Monteiro MJ, Cleveland DW (1990) Assembly properties of dominant and recessive mutations in the small mouse neurofilament (NF-L) subunit. J Cell Biol 111:2005-2019.

Ginty DD, Segal RA (2002) Retrograde neurotrophin signaling: Trk-ing along the axon. Curr Opin Neurobiol 12:268-274.

Gloster A, Diamond J (1992) Sympathetic nerves in adult rats regenerate normally and restore pilomotor function during an anti-NGF treatment that prevents their collateral sprouting. J Comp Neurol 326:363-374.

Goldstein ME, Grant P, House SB, Henken DB, Gainer H (1996) Developmental regulation of two distinct neuronal phenotypes in rat dorsal root ganglia. Neuroscience 71:243-258.

Gorham JD, Baker H, Kegler D, Ziff EB (1990) The expression of the neuronal intermediate filament protein peripherin in the rat embryo. Brain Res Dev Brain Res 57:235-248.

Goudeau B, Dagvadorj A, Rodrigues-Lima F, Nedellec P, Casteras-Simon M, Perret E, Langlois S, Goldfarb L, Vicart P (2001) Structural and functional analysis of a new desmin variant causing desmin-related myopathy. Hum Mutat 18:388-396. 
Helfand BT, Mikami A, Vallee RB, Goldman RD (2002) A requirement for cytoplasmic dynein and dynactin in intermediate filament network assembly and organization. J Cell Biol 157:795-806.

Helmrath MA, VanderKolk WE, Can G, Erwin CR, Warner BW (1996) Intestinal adaptation following massive small bowel resection in the mouse. J Am Coll Surg 183:441-449.

Inada H, Izawa I, Nishizawa M, Fujita E, Kiyono T, Takahashi T, Momoi T, Inagaki M (2001) Keratin attenuates tumor necrosis factor-induced cytotoxicity through association with TRADD. J Cell Biol 155:415-426.

Inbal R, Rousso M, Ashur H, Wall PD, Devor M (1987) Collateral sprouting in skin and sensory recovery after nerve injury in man. Pain 28:141-154.

Jackson PC, Diamond J (1984) Temporal and spatial constraints on the collateral sprouting of low-threshold mechanosensory nerves in the skin of rats. J Comp Neurol 226:336-345.

Julien JP (1999) Neurofilament functions in health and disease. Curr Opin Neurobiol 9:554-560.

Kirschstein T, Greffrath W, Busselberg D, Treede RD (1999) Inhibition of rapid heat responses in nociceptive primary sensory neurons of rats by vanilloid receptor antagonists. J Neurophysiol 82:2853-2860.

Korsching S, Thoenen H (1985) Nerve growth factor supply for sensory neurons: site of origin and competition with the sympathetic nervous system. Neurosci Lett 54:201-205.

Landmesser L, Swain S (1992) Temporal and spatial modulation of a cytoskeletal antigen during peripheral axonal pathfinding. Neuron 8:291-305.

Lariviere RC, Nguyen MD, Ribeiro-Da-Silva A, Julien JP (2002) Reduced number of unmyelinated sensory axons in peripherin null mice. J Neurochem 81:525-532.

Leonard DG, Ziff EB, Greene LA (1987) Identification and characterization of mRNAs regulated by nerve growth factor in PC12 cells. Mol Cell Biol 7:3156-3167.

Leonard DG, Gorham JD, Cole P, Greene LA, Ziff EB (1988) A nerve growth factor-regulated messenger RNA encodes a new intermediate filament protein. J Cell Biol 106:181-193.

Lepekhin EA, Eliasson C, Berthold CH, Berezin V, Bock E, Pekny M (2001) Intermediate filaments regulate astrocyte motility. J Neurochem 79:617-625

Lourenssen S, Motro B, Bernstein A, Diamond J (2000) Defects in sensory nerve numbers and growth in mutant Kit and Steel mice. NeuroReport 11:1159-1165.

MacDonald JI, Verdi JM, Meakin SO (1999) Activity-dependent interaction of the intracellular domain of rat trkA with intermediate filament proteins, the beta- 6 proteasomal subunit, Ras-GRF1, and the p162 subunit of eIF3. J Mol Neurosci 13:141-158.

Mearow KM, Kril Y, Diamond J (1993) Increased NGF mRNA expression in denervated rat skin. NeuroReport 4:351-354.

Molliver DC, Radeke MJ, Feinstein SC, Snider WD (1995) Presence or absence of TrkA protein distinguishes subsets of small sensory neurons with unique cytochemical characteristics and dorsal horn projections. J Comp Neurol 361:404-416.

Nixon BJ, Doucette R, Jackson PC, Diamond J (1984) Impulse activity evokes precocious sprouting of nociceptive nerves into denervated skin. Somatosens Res 2:97-126.

Oblinger MM, Wong J, Parysek LM (1989) Axotomy-induced changes in the expression of a type III neuronal intermediate filament gene. J Neurosci 9:3766-3775.

Parysek LM, Goldman RD (1987) Characterization of intermediate filaments in PC12 cells. J Neurosci 7:781-791.
Parysek LM, Goldman RD (1988) Distribution of a novel $57 \mathrm{kDa}$ intermediate filament (IF) protein in the nervous system. J Neurosci 8:555-563.

Parysek LM, McReynolds MA, Goldman RD, Ley CA (1991) Some neural intermediate filaments contain both peripherin and the neurofilament proteins. J Neurosci Res 30:80-91.

Raats JM, Schaart G, Henderik JB, van der Kemp A, Dunia I, Benedetti EL, Pieper FR, Ramaekers FC, Bloemendal H (1996) Muscle-specific expression of a dominant negative desmin mutant in transgenic mice. Eur J Cell Biol 71:221-236.

Sambrook J, Fritsch EF, Maniatis T (1989) Molecular cloning: a laboratory manual, Ed 2. Cold Spring Harbor, NY: Cold Spring Harbor Laboratory.

Smith DS, Skene JH (1997) A transcription-dependent switch controls competence of adult neurons for distinct modes of axon growth. J Neurosci 17:646-658.

Tennyson VM, Gershon MD (1984) Light and electron microscopy of dorsal root, sympathetic, and enteric ganglia. In: Peripheral neuropathy (Dyck PJ, Thomas PK, Lambert EH, Bunge R, eds), pp 121-207. Philadelphia: Saunders.

Thompson MA, Ziff EB (1989) Structure of the gene encoding peripherin, an NGF-regulated neuronal-specific type III intermediate filament protein. Neuron 2:1043-1053.

Thompson MA, Lee E, Lawe D, Gizang-Ginsberg E, Ziff EB (1992) Nerve growth factor-induced derepression of peripherin gene expression is associated with alterations in proteins binding to a negative regulatory element. Mol Cell Biol 12:2501-2513.

Tjolsen A, Rosland JH, Berge OG, Hole K (1991) The increasingtemperature hot-plate test: an improved test of nociception in mice and rats. J Pharmacol Methods 25:241-250.

Troy CM, Brown K, Greene LA, Shelanski ML (1990a) Ontogeny of the neuronal intermediate filament protein, peripherin, in the mouse embryo. Neuroscience 36:217-237.

Troy CM, Muma NA, Greene LA, Price DL, Shelanski ML (1990b) Regulation of peripherin and neurofilament expression in regenerating rat motor neurons. Brain Res 529:232-238.

Vassar R, Coulombe PA, Degenstein L, Albers K, Fuchs E (1991) Mutant keratin expression in transgenic mice causes marked abnormalities resembling a human genetic skin disease. Cell 64:365-380.

Voyvodic JT (1989) Target size regulates calibre and myelination of sympathetic axons. Nature 342:430-433.

Walker KL, Yoo HK, Undamatla J, Szaro BG (2001) Loss of neurofilaments alters axonal growth dynamics. J Neurosci 21:9655-9666.

Wilkinson KD, Lee KM, Deshpande S, Duerksen-Hughes P, Boss JM, Pohl J (1989) The neuron-specific protein PGP 9.5 is a ubiquitin carboxylterminal hydrolase. Science 246:670-673.

Wong J, Oblinger MM (1990) Differential regulation of peripherin and neurofilament gene expression in regenerating rat DRG neurons. J Neurosci Res 27:332-341.

Yano H, Lee FS, Kong H, Chuang J, Arevalo J, Perez P, Sung C, Chao MV (2001) Association of Trk neurotrophin receptors with components of the cytoplasmic dynein motor. J Neurosci 21:RC125.

Zhang Z, Casey DM, Julien JP, Xu Z (2002) Normal dendritic arborization in spinal motoneurons requires neurofilament subunit L. J Comp Neurol 450:144-152.

Zhu Q, Couillard-Despres S, Julien JP (1997) Delayed maturation of regenerating myelinated axons in mice lacking neurofilaments. Exp Neurol 148:299-316 